OPEN ACCESS

Edited by:

Lianbiao Cui,

Anhui University of Finance and

Economics, China

Reviewed by:

Muhammad Luqman,

Qingdao University, China

Suleman Sarwar,

Jeddah University, Saudi Arabia

Diogo Ferraz,

Universidade Federal de Ouro Preto

Brazil

${ }^{*}$ Correspondence:

Muhammad Zahid Rafique

zahid716@sdu.edu.cn

Specialty section:

This article was submitted to

Environmental Economics and

Management,

a section of the journal

Frontiers in Environmental Science

Received: 18 September 2021

Accepted: 19 October 2021

Published: 01 November 2021

Citation:

Deqiang $S$, Zhijun $C$

Hajduk-Stelmachowicz M, Larik $A R$ and Rafique MZ (2021) The Role of the Global Value Chain in Improving Trade and the Sustainable Competitive Advantage: Evidence From China's

Manufacturing Industry.

Front. Environ. Sci. 9:779295.

doi: 10.3389/fenvs.2021.779295

\section{The Role of the Global Value Chain in Improving Trade and the Sustainable Competitive Advantage: Evidence From China's Manufacturing Industry}

\author{
Shi Deqiang ${ }^{1}$, Chen Zhijun ${ }^{1}$, Marzena Hajduk-Stelmachowicz ${ }^{2}$, Abdul Razaque Larik ${ }^{3}$ and \\ Muhammad Zahid Rafique ${ }^{4 *}$
}

${ }^{1}$ School of Management, Shandong University, Jinan, China, ${ }^{2}$ Department of Economics, Rzeszow University of Technology Rzeszow, Poland, ${ }^{3}$ General Department, Government College University, Hyderabad, Pakistan, ${ }^{4}$ Centre for Economic Research, Shandong University, Jinan, China

In the domain of globalization, the global value chain (GVC) is formed across diverse economies. Owing to the expansion of economic globalization and the resultant global trade liberalization, the geographical isolation of production and consumption has resulted in the transfer of polluting emissions from advanced economies to developing states. Developing economies, falling in the middle and low end of the GVC, have to strive hard to expand their production in the GVC, while simultaneously addressing the consequent environmental damage and attending to the core environmental concerns of sustainable growth, energy preservation and drastic cuts in $\mathrm{CO}_{2}$. This paper addresses how manufacturing subsidiaries can improve their low-carbon innovation ability and help to achieve a sustainable competitive advantage through the embedded GVC. Data were gathered employing interview and survey methods, 31 manufacturing companies and 56 enterprise groups across 16 Chinese provinces were selected as the case study. A partial least square structural equation modelling was adopted to analyse the responses. The results indicate that the embedded GVC significantly enhances low-carbon innovation capability and promotes a sustainable competitive advantage. This study proposes that companies should continuously identify high-quality resources from the GVC and discover ways of integrating internal and external carbon innovation resources to form innovation capabilities.

Keywords: global value chain, manufacturing subsidiaries, low carbon innovation capability, sustainable competitive advantage, trade

\section{INTRODUCTION}

The establishment of the global value chain (GVC) allows firms to minimize production costs across the entire production system. As the GVC becomes a dominant feature of trading, the principle of comparative advantage in trading is reflected in the various stages of production instead of "bundled" goods and services. It is highly encouraging that the promotion of GCV embedding is more helpful to developing economies, in comparison to the developed ones, because it enhances energy capacity and enables the latter to minimize $\mathrm{CO}_{2}$ emissions (Sun C. et al., 2019; Polloni-Silva et al., 2021). It should be noted that the current state of the manufacturing sector relating to GVC embedding makes up the 
most noticeable attribute of trade and investment globally. The model of processing trade which China follows has been designed to integrate the manufacturing industry into the GVC. On account of its stature as the backbone of the Chinese economy, the growth of the manufacturing industry affects all sectors and has a huge impact on the future of the country (Tian et al., 2018). The competitiveness of the manufacturing industry is significantly associated with sustainable manufacturing and its carbon efficiency in the supply chain. The awareness is on the rise for environmental protection, based on factors such as emission cuts and climate change (Ferraz et al., 2018, 2021; Doğan et al., 2020; Siwiec and Pacana, 2021; Pacana et al., 2020; Shahzad et al., 2020, 2022). In addition to the cost efficiency, network optimization, profit maximization, risk reduction, and valueadded services, the contemporary manufacturing industries have recently incorporated reductions in their carbon footprint to their performance indices (Tiwari et al., 2015; Centobelli et al., 2018).

Since the 1990s, the Chinese manufacturing sector, by virtue of trade and investment, has achieved tremendous milestones driven by the global manufacturing network. However, its further premium growth has been hampered by the resulting environmental degradation. The available data on environmental health reveal that around $70 \%$ of the global pollution is caused by the Chinese manufacturing sector, which produces nearly 700 million tons of environmentally-damaging waste per annum. The Central Economic Working Conference, organized in 2014, suggested that the capability of China to pay due attention to the environment had been stretched to its limits and that it was high time to search for a model that was environmentally friendly and founded on preferences for low-carbon. At present, the Chinese Organization of International Production has been overhauled and a gradual shift has been witnessed towards intra-product specialization that has transformed the manufacturing sector into a highly complex one ( $\mathrm{Yu}$ and Luo, 2018). The upgrading of all the production processes to incorporate more advanced technology inevitably leads to a major increase in costs, despite the significant reduction in emissions. Since most enterprises are essentially profitoriented, the pursuit of green technology in manufacturing processes is not of significant interest to them. Therefore, it is high time that the pace of the innovation factor input to output effect should be maximized; while $\mathrm{CO}_{2}$ emissions must be minimized. The year 2018 marked the execution phase of "made in China 2025" suggesting a win-win policy that simultaneously attends to the protection of the environment and also the development of the manufacturing sector. Currently, the Chinese manufacturing sector is under stress from both the domestic and international governments to limit the high-end of the value chain. The recent discourse argues that developing economies, especially China, should strive for knowledge spillovers employing the means of foreign direct investment (FDI), outward foreign direct investment (OFDI), and import and export trade that are all helpful for pro-green development (Qu et al., 2020; Shahzad et al., 2020, 2021; Wang et al., 2021). Under the "new normal" model, the Chinese economy should enhance the quality and sustainability of economic development in order to improve the total factor productivity employing GVC embeddedness. For sustainable economic development worldwide, the environmentally friendly growth path plays a key role in minimizing the greenhouse effect (Sun H. et al., 2019). However, most manufacturers seek to optimize their profits and are unwilling to manufacture low-carbon goods unless they are offered certain incentives (Li et al., 2019). Apart from the concerns by consumers and firms on low-carbon goods, coordination plays a key role in the low-carbon supply chain production (Zhou et al., 2016).

The resource-based view (RBV) postulates that enterprises possess unique physical and intangible resources that may have exceptional potential to produce a sustainable competitive advantage (Wernerfelt, 1984; Chahal et al., 2020; Safari and Saleh, 2020; Shibin et al., 2020). A few studies have shown that firms that are embedded in the GVC can gain new skills and obtain specialized knowledge (Defraigne, 2017; Mentel and Hajduk-Stelmachowicz, 2020). However, two major research gaps are known to exist in literature. Firstly, although existing studies have explored the benefits of transfer from parent companies, the continuous subsidiary innovation capabilities have been poorly studied in these companies (Tang et al., 2018). Secondly, researchers have investigated the impact of global collaborative research and development ( $R$ and $D$ ) activities on subsequent innovation performance without emphasizing the micro-level interactions of key associations between the GVC and the low-carbon innovation capability (Yu and Luo, 2018; Sun H. et al., 2019; Qu et al., 2020; Ryan et al., 2020). To fill the existing research gap between the GVC embedding, the low carbon innovation capability and the sustainable competitive advantage, this study aims to achieve three objectives based on the following: a) investigate the direct effects of three different embedded in the GVC on the low-carbon innovation capability and the direct effects of four different low carbon innovation capabilities on the sustainable competitive advantage of the subsidiaries, b) validate the mediating role of the low-carbon technology innovation capability with embedment in the GVC and a sustainable competitive advantage, and c) provide a reference case study for business group managers to manage and efficiently control the manufacturing subsidiaries, due to the lack of research regarding globalization and low-carbon innovation of business groups and multinational corporations in developing countries.

\section{LITERATURE REVIEW AND HYPOTHESES}

RBV highlights the importance of building an external network for the process of innovation (Wernerfelt, 1984; Chahal et al., 2020; Safari and Saleh, 2020; Shibin et al., 2020). Scholars have broken up the establishment of the GVC in the manufacturing industry into three major types: technology, production, and marketing (Galbraith, 1982). Pananond, (2013) identified the link between the GVC in $\mathrm{R}$ and $\mathrm{D}$, manufacturing, and Original Equipment Manufacturers (OEMs) as well as in sales and marketing from the perspective of diffusion knowledge. Apart from the creation of value-added products, value chains 
can be divided into high value-added activities, for instance technological $\mathrm{R}$ and $\mathrm{D}$ and marketing, as well as low valueadded activities, those involved in production assembly from the perspective of brand marketing (Sears, 2017). Although there is a range of value-added divisions that are embedded in the GVC of the manufacturing industry, most of the divisions have three common key activities, which include $\mathrm{R}$ and $\mathrm{D}$, manufacturing, and marketing.

\section{Dimensions of the Embedded GVC Associated With Low Carbon Innovation Capability}

The embedment of global low-carbon $\mathrm{R}$ and $\mathrm{D}$ is the main driving force in business groups and their manufacturing subsidiaries to create high value-added products. The fundamental idea of being embedded in global low-carbon $\mathrm{R}$ and $\mathrm{D}$ is the promotion of $\mathrm{R}$ and $\mathrm{D}$ activities in enterprises to create value in a global context. The embedment of global low-carbon $\mathrm{R}$ and $\mathrm{D}$ for business groups takes diverse forms, although cooperation in $\mathrm{R}$ and $\mathrm{D}$ and the establishment of overseas $\mathrm{R}$ and $\mathrm{D}$ branches are the primary forms (Zheng and Shi, 2017). The extent to which global $\mathrm{R}$ and $\mathrm{D}$ is embedded depends on the level of input of the manufacturing subsidiaries to the global $\mathrm{R}$ and $\mathrm{D}$ activities, which include $\mathrm{R}$ and $\mathrm{D}$ funding, personnel, and patent outputs. $\mathrm{R}$ and $\mathrm{D}$ activities are primarily associated with technological innovation. A large amount of cutting-edge knowledge can be accumulated to form and upgrade technological innovation capability based on $R$ and $D$ activities. $\mathrm{R}$ and $\mathrm{D}$ activities are also associated with the system, capital, and management efficiency, in which higher efficiency levels are thought to affect the overall capability of innovation. Owing to globalization, scholars have emphasized the positive effects of $\mathrm{R}$ and $\mathrm{D}$ globalization on the innovation capability of enterprises, as well as the positive effects of the $\mathrm{R}$ and $\mathrm{D}$ activities of multinational corporations on the innovation capability of their host countries in underdeveloped countries (Binz and Truffer, 2017; Mayer and Phillips, 2017). From the perspective of global climate change, Ockwell et al. (2015) indicated that international cooperation in climate technology $\mathrm{R}$ and $\mathrm{D}$ can greatly support the transfer of low-carbon technologies to developing states for absorption into their current technological processes. Consequently, the current study proposes the following hypotheses:

$\mathrm{H} 1$. The embedment of global low-carbon $\mathrm{R}$ and $\mathrm{D}$ exerts a positive effect on the low-carbon innovation capability of manufacturing subsidiaries.

H1a. The embedment of global low-carbon R and D exerts a positive effect on the low-carbon technology innovation capability of manufacturing subsidiaries.

H1b. The embedment of global low-carbon R and D exerts a positive effect on the low-carbon system innovation capability of manufacturing subsidiaries.

H1c. The embedment of global low-carbon R and D exerts a positive effect on the low-carbon management innovation capability of manufacturing subsidiaries.
The embedment of global low-carbon manufacturing is another important value creation activity that refers to the process of embedding in the global production chain, decreasing carbon emissions in the production process, and producing more low-carbon products. The main measures involved in this activity include low-carbon production equipment input, advanced levels of low-carbon production technology, and staff skills. The main mode used by developing countries to participate in global manufacturing is through OEMs.

Some scholars have justified the positive effect of the OEM participation mode on the innovation ability of developing countries (Morrison et al., 2007; Tridech and Cheng, 2011). In the long run, the OEM is not a conducive method to enhance the ability of independent innovation, although it is a key channel used to acquire advanced foreign knowledge and facilitates the improvement of the technology capability, institution, and management innovation in developing countries. Besides, the influx of different types of global intellectual capital has become a driving force of innovation in the manufacturing process. From the perspective of business groups, the business group headquarters provide product-specific information to their foreign subsidiaries. Hence, if the low-carbon manufacturing level in that foreign country is worse than the host country, these subsidiaries can become embedded in the host country market to obtain advanced product knowledge (Chahal et al., 2020; Safari and Saleh, 2020; Shibin et al., 2020). Therefore, the present study proposes the following hypotheses:

$\mathrm{H} 2$. The embedment of global low-carbon manufacturing exerts a positive effect on the low-carbon innovation capability of manufacturing subsidiaries.

$\mathrm{H} 2 \mathrm{a}$. The embedment of global low-carbon manufacturing exerts a positive effect on the low-carbon technology innovation capability of manufacturing subsidiaries.

$\mathrm{H} 2 \mathrm{~b}$. The embedment of global low-carbon manufacturing exerts a positive effect on the low-carbon system innovation capability of manufacturing subsidiaries.

$\mathrm{H} 2 \mathrm{c}$. The embedment of global low-carbon manufacturing exerts a positive effect on the low-carbon capital innovation capability of manufacturing subsidiaries.

$\mathrm{H} 2 \mathrm{~d}$. The embedment of global low-carbon manufacturing exerts a positive effect on the low-carbon management innovation capability of manufacturing subsidiaries.

The global low-carbon marketing strategy of embedment involves the global trading of low-carbon products, the carbon emission reduction process, and the realization of the value of low-carbon products. The embedment of global marketing for innovation knowledge is primarily achieved by establishing an overseas subsidiary in a business group. The manufacturing subsidiaries can fully understand the needs of local consumers. Additionally, during the process of purchasing and marketing, manufacturing subsidiaries can obtain useful information on advanced products in developed countries and subsequently transfer and absorb them into the internal innovation capability of subsidiaries. In a global environment, global marketing strategies are dynamically impacted by technology, systems, management and capital arrangements. Compared with 
the system and capital, the greater demand for Chinese subsidiaries with a certain capital strength to participate in global marketing cooperation lies in the world's advanced lowcarbon technology and management experience. Hence, implementing the global low-carbon marketing strategy is required to strengthen the manufacturing subsidiary of the technology and management innovation. Studies have shown that marketing capabilities can help companies to identify the right innovation direction (Zhang et al., 2017). The existing literature offers support for a significant positive association between marketing capability and innovation in firms (Weerawardena, 2003; Tian et al., 2018; Sun C. et al., 2019). Therefore, we propose the following hypotheses:

H3. The embedment of global low-carbon marketing exerts a positive effect on the low-carbon innovation capability of manufacturing subsidiaries.

H3a. The embedment of global low-carbon marketing exerts a positive effect on the low-carbon technology innovation capability of manufacturing subsidiaries.

$\mathrm{H} 3 \mathrm{~b}$. The embedment of global low-carbon marketing exerts a positive effect on the low-carbon management innovation capability of manufacturing subsidiaries.

\section{Dimensions of Low-Carbon Innovation Capability}

The RBV indicates that the core technology resources are heterogeneous and scarce, thereby representing the basis of independent innovation of the enterprises (Wernerfelt, 1984). Technological innovation is called one of the major sources of sustainable competitive advantage in the value network. For instance, it represents the process of knowledge being used in the flow, integration and process of new knowledge being created and discovered. The sustainable competitive advantage of an organization is reflected in the amount of excess profits obtained by the organization. For instance, innovative enterprises can get a first-mover advantage to help enterprises obtain monopoly profits (Uyarra et al., 2016). The constituent elements of sustainable competitive advantage are characterized by non-repeatability, exclusivity, and specificity (Lai et al., 2017). Technological innovation capability is related to $\mathrm{R}$ and $\mathrm{D}$ conditions and technical levels (Dierickx and Cool, 1989). R and $\mathrm{D}$ conditions and technical levels positively affect sustainable competitive advantage, although the latter's effect is larger. Green technology and low-carbon technology innovation capability are special subsidiaries of manufacturing quality resources that significantly enhance the sustainable competitive advantage (Liu et al., 2017). Therefore, the study proposes the following hypothesis:

H4. The low-carbon technology innovation capability exerts a positive effect on the sustainable competitive advantage of manufacturing subsidiaries.

The institution refers to certain restrictions imposed by people to determine the relationship between people. Based on the perspectives of the system, resources, and innovation, the sustainable competitive advantage of enterprises is derived from the heterogeneity of resources and ability. Additionally, it also depends on whether the behavior of the enterprise complies with sustainable practices that originate from sustainable institutional innovations and are recognized by the community. Some scholars have indicated that the strategies for a green-sustainable competitive advantage comprise three dimensions: a strategic network structure, energy conservation, and an environmental protection system (Stead and Stead, 2000; Ngah et al., 2015). Institutional factors, such as low-carbon laws and law enforcement systems, the implementation of the quality of the contract, the implementation of the contract, and the implementation of efficiency are more important sources of trade comparative advantage (Timmerman et al., 2017). Therefore, this study proposes the following hypothesis:

H5. The low-carbon system innovation capability exerts a positive effect on the sustainable competitive advantage of manufacturing subsidiaries.

Low-carbon capital innovation refers to the capital arrangements for low-carbon technologies, institutions, management, and market innovation. Low-carbon capital is a special resource used by manufacturing subsidiaries to maintain a sustainable competitive advantage. In addition, low-carbon technology is capital intensive high technology. Manufacturing subsidiaries in developing countries often limit the improvement of low-carbon technological innovation capacity due to restrictions in the capital. Enterprise innovation capital includes internal and external forms such as social capital, FDI, green capital and human capital. The effective combination and efficient use of capital guarantees the lowcarbon sustainable competitive advantage (Chen et al., 2016). Researchers have found a positive association between greenhouse gas emission reduction and enterprise value. Shareholders and investors are more likely to decrease greenhouse gas emissions and thereby enhance the company's value (Nishitani and Kokubu, 2012). Therefore, this study proposes the following hypothesis:

H6. The low-carbon capital innovation capability exerts a positive effect on the sustainable competitive advantage of manufacturing subsidiaries.

Management innovation is a more effective resource integration concept that acts as the foundation for other successful sources of innovation. To obtain a sustainable competitive advantage for low-carbon products and technology, companies must strengthen their management innovation ability to manage manufacturing subsidiaries from the perspective of strategic management (Masri and Jaaron, 2017). The effective management of innovation knowledge positively influences the sustainable competitive advantage of enterprises. Moreover, knowledge management is also a process of organizational learning. In contrast to individual companies, the manufacturing subsidiarie's sustainable competitive advantage resources are derived from both the internal parent company and the external network. However, a subsidiary must integrate resources and form an independent innovation ability that is separate from the effective management of internal and external knowledge (Varadarajan, 2017). Therefore, this study proposes the following hypothesis: 


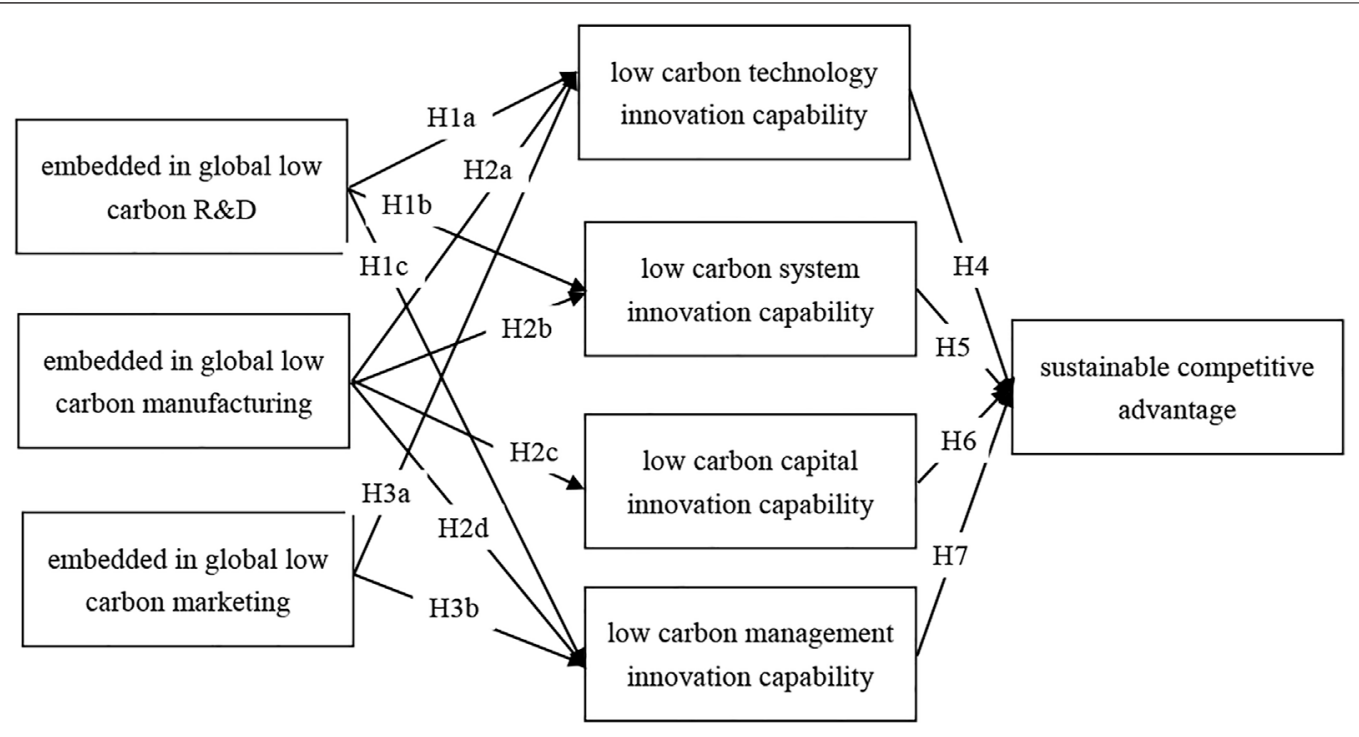

FIGURE 1 | Conceptual model of the influence of embedment in the GVC on a sustainable competitive advantage.

H7. The low-carbon management innovation capability exerts a positive effect on the sustainable competitive advantage of manufacturing subsidiaries.

\section{The Mediating Effect of the Low-Carbon Innovation Capability}

The resource-based theory argues that sustainable competitive advantage resources are heterogeneous and it is difficult for them to flow freely, thereby representing the key determinants of firm value (Wernerfelt, 1984). The intangible resources possessed by the enterprise are important sustainable competitive advantage resources that are highly specific and can be utilized to create high value for the business activities of enterprises (Barney, 1991). Manufacturing subsidiaries have a strong relationship with key stakeholders through embedment of the GVC, thereby helping them to gain access to intangible resources to create a sustainable competitive advantage and ultimately enhance their corporate value. The low-carbon innovation capability is the key intangible resource for manufacturing subsidiaries embedded in global low carbon $\mathrm{R}$ and $\mathrm{D}$, manufacturing, and marketing. These intangible resources can produce diverse products or services at lower costs, higher quality or gain a sustainable competitive advantage for manufacturing subsidiaries, and resultantly enhance corporate value. Although manufacturing subsidiaries can gain new knowledge from the key factors embedded in the GVC, these enterprises do not gain from innovation if they cannot effectively reorganize the new knowledge elements and the existing knowledge elements. The competitiveness of a global subsidiary is defined in terms of its capability to promote in the GVC and involve itself in higher value-adding activities (Ryan et al., 2020). The low-carbon innovation capability is a significant factor in enterprise innovation and a vital source of an enterprise sustainable competitive advantage. Therefore, we propose the following hypotheses:
H8. The low-carbon innovation capabilities play a mediating role between embedment in the GVC and a sustainable competitive advantage.

H8a. The low-carbon innovation capabilities play a mediating role between embedment in global low carbon $\mathrm{R}$ and $\mathrm{D}$ and a sustainable competitive advantage.

H8b. The low-carbon innovation capabilities play a mediating role between embedment in global low carbon manufacturing and a sustainable competitive advantage.

H8c. The low-carbon innovation capabilities play a mediating role between embedment in global low carbon marketing and a sustainable competitive advantage.

\section{Conceptual Model}

The following conceptual model (Figure 1) is proposed in this study based on the GVC theory, innovation theory and competitive advantage theory, combined with the above assumptions.

\section{RESEARCH DESIGN}

\section{Sample and Data Collection}

The proposed model was tested based on a questionnaire survey provided to senior subsidiary managers in fully owned subsidiaries of Chinese business groups. According to the national economic classification system, implemented by the state in 2017, representative samples were selected from 31 manufacturing industries. Additionally, the samples were selected from enterprise groups with more than five holding subsidiaries in the manufacturing industry. Based on detailed and in-depth discussions with the relevant experts and senior management, the questionnaire draft was designed and modified several times after a trial survey, prior to preparation of the final draft. The raw data was collected based on a survey of 
60 subsidiaries from 56 Chinese business groups that were engaged in global low-carbon $\mathrm{R}$ and $\mathrm{D}$, manufacturing, and marketing activities. The firms selected for the survey were invited to answer the questionnaire based on the activities in their respective locations individually. Reminders were sent to the headquarters of each participating company through phone to ensure that the senior executives completed the questionnaires. Besides, assistance was provided if there were any issues in answering the questions. 300 questionnaires were distributed.

The questionnaire collection process was divided into two stages. In the first stage, 200 questionnaires were distributed and finally 180 valid questionnaires were received back in 2019. A follow-up survey was carried out in 2021, 100 questionnaires were distributed, and finally 49 valid questionnaires were received back. By conducting these separate surveys, we were able to obtain more information on the enterprise as well as identify the enterprises that were more suitable for this research. One possible reason for the lack of response from some of the companies was that the subsidiaries could have been withdrawn from the global market. In total, 229 valid questionnaires were obtained, accounting for $76.3 \%$ of the total number of questionnaires (See questionnaire in Supplementary Material).

\section{Definition and Measurement of Study Dimensions \\ Endogenous Latent Variable}

A sustainable competitive advantage can be assessed based on four aspects consisting of; price/cost, quality, product innovation, and time-to-market (Li et al., 2006). A sustainable competitive advantage may be described as the situation when an organization creates a defensible position over its competitors, in which the four aspects mentioned above were included and measured on a 5-point Likert's scale (1-very inconsistent; 2-not consistent; 3-basically consistent; 4-more consistent; 5-very consistent), thus providing the construct of a sustainable competitive advantage.

\section{Exogenous Latent Variables}

This study defines embedment in the GVC as the high valueadded creation activity of global low-carbon $R$ and $D$, manufacturing, and marketing to improve the low-carbon innovation capabilities of manufacturing subsidiaries. For the case studies involving the Chinese business groups, all the components of these Chinese manufacturing subsidiaries were highly embedded in the GVC, particularly in low-carbon R and $\mathrm{D}$, manufacturing, and marketing activities (Bi et al., 2016). Therefore, the GVC framework was integrated as the analytical framework into this study to explore low-carbon technological innovation activities, based on embedment in the GVC, in three components: global low-carbon R and D, lowcarbon manufacturing, and low-carbon marketing. In this study, 12 items were used to measure the embedment in the GVC of global low-carbon R and D, low-carbon manufacturing, and lowcarbon marketing on a 5-point Likert's scale (1-very inconsistent; 2-not consistent; 3-basically consistent; 4-more consistent; 5-very consistent).

The four dimensions of low-carbon innovation capabilities include low-carbon technology innovation capability, low-carbon system innovation capability, low-carbon capital innovation capability, and low-carbon management innovation capability. This study defines low-carbon innovation capabilities as the ability for manufacturing subsidiaries to integrate domestic and foreign resources as an intangible asset that helps to enhance their sustainable competitive advantage. In total, 15 items were used to measure the low-carbon innovation capabilities on a 5-point Likert's scale (1-very inconsistent; 2-not consistent; 3-basically consistent; 4-more consistent; 5 -very consistent). Table 1 shows the Index system and its sources of influence of embedment in the GVC on the sustainable competitive advantage for Chinese manufacturing subsidiaries.

\section{RESULTS AND DISCUSSION}

The hypotheses outlined in this study were examined using structural equation modelling (SEM). SEM was employed to analyze complex, causal relationships among the multiple variables present in this study and evaluate their associations with the proposed model. Hence, the SEM method rendered the realization of both analytical objectives, unlike other analytical methods, such as regression analysis (Fornell and Larcker, 1981). Nevertheless, it is difficult to model type 2 higher-order variables with covariance-based SEM. Therefore, the component-based SEM method, known as Partial Least Squares (PLS), was also employed to achieve the study objectives. PLS is a more suitable technique compared to covariance-based SEM, particularly if a prediction outcome is required. Additionally, for the analysis of a complex model, such as the one proposed in this study, the PLS approach requires a significantly smaller sample size as opposed to covariance-based SEM, furthermore, it could deal equally with the formative and reflective indicators of latent variables, requires minimum measurement scales and the data are required to be normally scattered.

\section{Descriptive Statistics}

\section{Regional Distribution of the Samples}

Using the list of China's top 500 manufacturing enterprise groups in 2020, a sample of subsidiaries was selected. Figure 2 shows the regional distribution of the sample. The samples are concentrated in the Bohai economic circle, the Yangtze River Delta and the Pearl River Delta, indicating that the manufacturing industry in the eastern coastal areas is highly concentrated and participates in the GVC.

\section{Industry Distribution of the Samples}

According to China's national economy (GB/T 4754-2017), the distribution of subsidiary samples in 31 manufacturing subindustries was counted. Figure 3 shows the statistical results. From the distribution results, the respondents in food, furniture, pharmaceutical, and automobile manufacturing responded positively, indicating that these industries have a relatively 
TABLE 1 | Index system of variables and its sources.

Latent variables

Z1 embedded in global low-carbon $\mathrm{R}$ and D

Z2 embedded in global-low carbon manufacturing
Observed variables

Z11 Global low-carbon R and D personnel input level in manufacturing subsidiaries

Z12 Global low-carbon R and D capital input level in manufacturing subsidiaries Z13 Global low-carbon R and D patent numbers in manufacturing subsidiaries Z14 Low-carbon R and D equipment of an advanced degree in manufacturing subsidiaries

Z21 Global low-carbon production equipment input level in manufacturing subsidiaries

Z22 Global low-carbon production equipment of an advanced degree in manufacturing subsidiaries

Z23 Global low-carbon production - overall quality of staff in manufacturing subsidiaries

Z24 Global low-carbon manufacturing technology level in manufacturing subsidiaries
Z3 embedded in global-low carbon marketing

Z31 Global low-carbon marketing personnel input level in manufacturing subsidiaries

Z32 Global low-carbon marketing capital input level in manufacturing subsidiaries Z33 The international market degree of low-carbon products in manufacturing subsidiaries

Z34 International brand influence of low-carbon products in manufacturing subsidiaries

Z4 Low-carbon technology innovation capability

Z41 Low-carbon technology introduction capacity in manufacturing subsidiaries Z42 Low-carbon technology transformation capacity in manufacturing subsidiaries Z43 Low-carbon technology secondary innovation in manufacturing subsidiaries Z44 Low-carbon technology independent innovation in manufacturing subsidiaries

Z5 Low-carbon system innovation capability

\section{Z51 Low-carbon system imitative capability in manufacturing subsidiaries} Z52 Low-carbon system transplantation capability in manufacturing subsidiaries Z53 Low-carbon system reconstructing capability in manufacturing subsidiaries Z54 Low-carbon system executive capability in manufacturing subsidiaries
Z6 Low-carbon capital innovation capability

Z61 Low-carbon technology capital innovation capability in manufacturing subsidiaries

Z62 Low-carbon system capital innovation capability in manufacturing subsidiaries Z63 Low-carbon management capital innovation capability in manufacturing subsidiaries

Z64 Low-carbon market capital innovation capability in manufacturing subsidiaries
Z7 Low-carbon management innovation capability

Z71 Low-carbon management innovation input capability in manufacturing subsidiaries

Z72 Low-carbon management innovation transfer capability in manufacturing subsidiaries

Z73 Low-carbon management innovation output capability in manufacturing subsidiaries

Z8 sustainable competitive advantage
Z81 Low-carbon product price/cost advantage in manufacturing subsidiaries

Z82 Low-carbon product quality advantage in manufacturing subsidiaries
Items source

Balachandra and Friar, (1997); Hu et al. (2021)

Balachandra and Friar, (1997)

Lai et al. (2017)

Castellani and Zanfei, (2007)

Pietrobelli and Rabellotti, (2011)

Bi et al. (2016); Tian et al. (2019)

Bi et al. (2016)

Balachandra and Friar, (1997)

Balachandra and Friar, (1997); Wu et al (2010)

Hirsch-Kreinsen, (2011)

Bi et al. (2015)

Higgins et al. (2012)

Bi et al. (2015); Liu et al. (2017)

Castellani and Zanfei, (2007)

Pietrobelli and Rabellotti, (2011)

Bi et al. (2015)

Pietrobelli and Rabellotti, (2011)

Pietrobelli and Rabellotti, (2011)

Pietrobelli and Rabellotti, (2011)

Pietrobelli and Rabellotti, (2011)

Pietrobelli and Rabellotti, (2011)

Hall and Bagchi-Sen, (2002)

Morrison et al. (2007); Bi et al. (2015)

Defraigne, (2017)

Landsperger and Spieth, (2011)

Landsperger and Spieth, (2011)

Landsperger and Spieth, (2011)

Barney, (1991); Li et al. (2006)

Kumar and Motwani, (1995); Li et al.

(2006)

Ngah et al. (2015); Ryan et al. (2020)

Chen et al. (2016)

Z83 Low-carbon product innovation advantage in manufacturing subsidiaries

Z84 Low-carbon product time to market advantage in manufacturing subsidiaries

high participation in the GVC and high demands to improve the sustainable competitive advantage.

\section{Information Statistics of Respondents}

Although this study focuses on the GVC, it required input from individual participants representing their respective companies. In this respect, the views of supply chain managers and environmental specialists were considered. Different organizations have varied job titles for these roles, which are mentioned in Table 2. Figure 4 shows that
$39.30 \%$ of the respondents were from grassroots management and $20.09 \%$ from the low-carbon technology $R$ and $D$ department.

\section{Evaluation of the Measurement Model Reliability and Validity Test}

To obtain stable results, the reliability and validity tests of the questionnaire was first performed. The reliability tests employed in the current study were the Cronbach's alpha coefficient, which is recognized internationally, as well as the composite reliability 


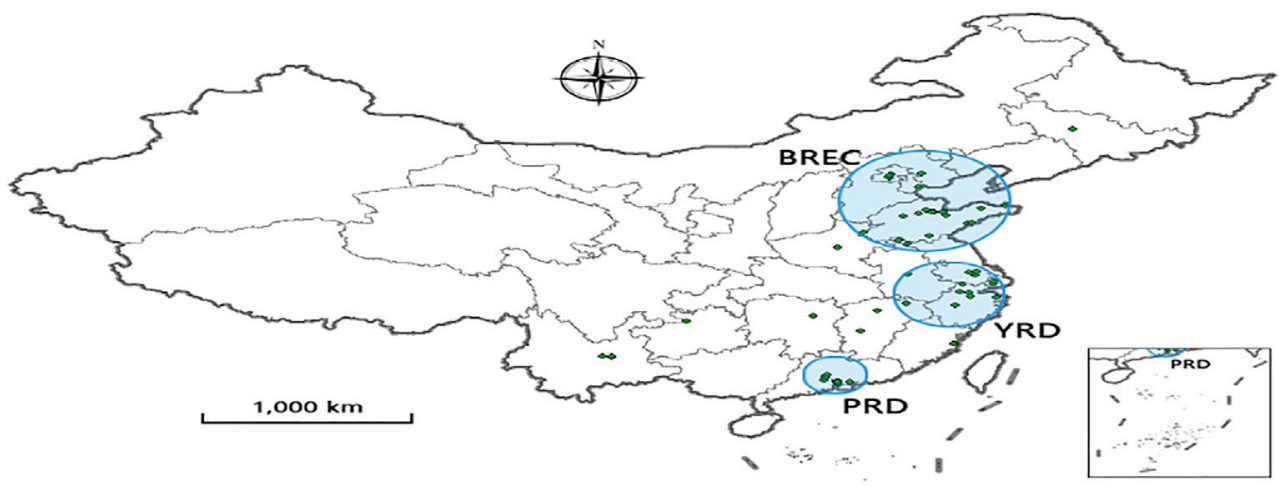

Note: BREC=Bohai Rim Economic Circle; $Y R D=$ Yangtze River Delta; $P R D=$ Pearl River Delta.

FIGURE 2 | Regional distribution statistics of samples. Note: BREC = Bohai Rim Economic Circle; YRD = Yangtze River Delta; PRD = Pearl River Delta.

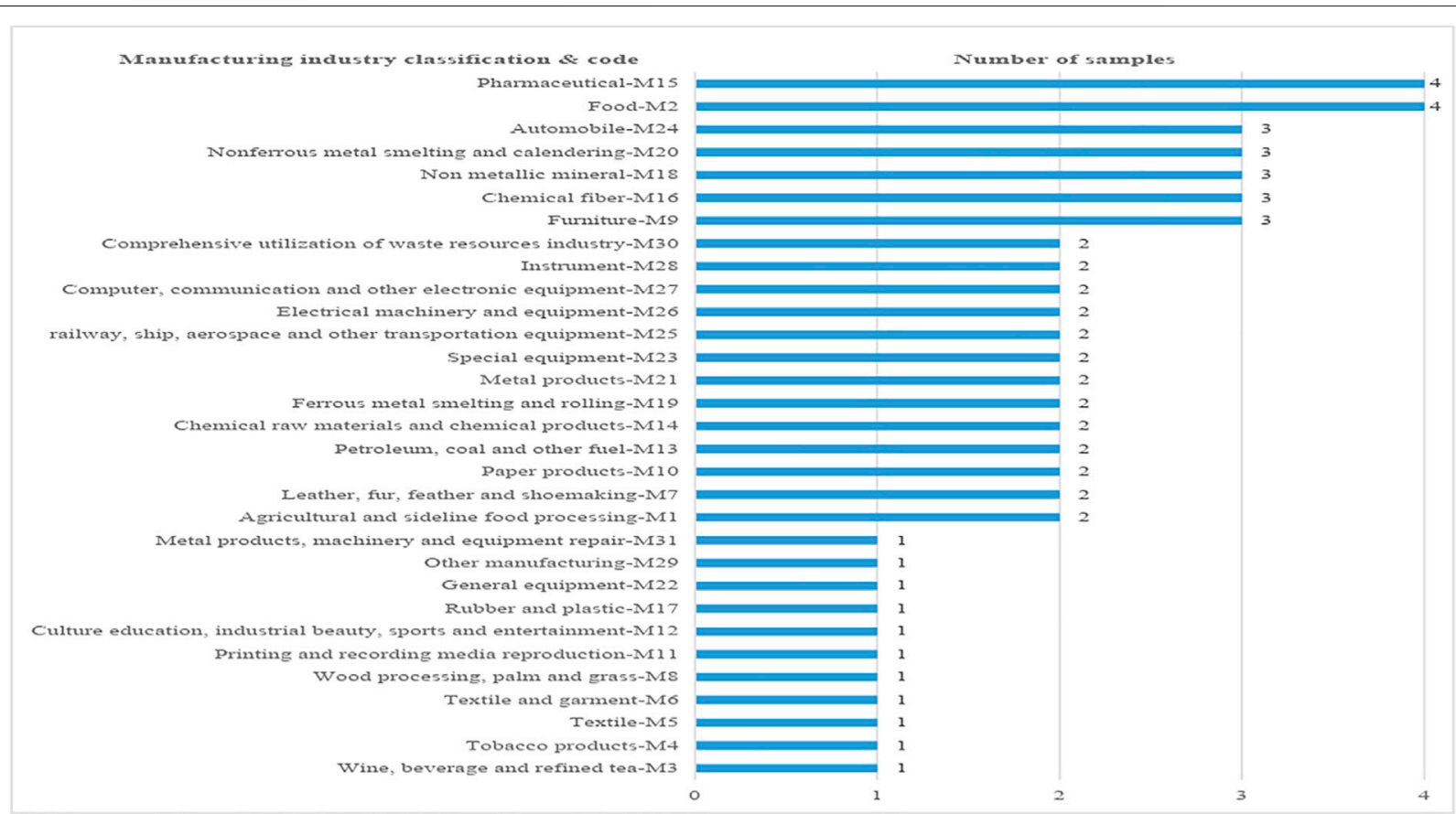

Source: http://www.stats.gov.cn/tjsj/tjbz/hyflbz/201710/t20171012_1541679.html

FIGURE 3 | Industry distribution statistics and No. of samples. Source: http://www.stats.gov.cn/tjsj/tjbz/hyflbz/201710/t20171012_1541679.html.

(CR) test. The Cronbach (Coefficient) Alpha is the most widely used method for estimating internal consistency. The Coefficient Alpha assumes: i) unidemsionality, and that ii) items are equally related to the construct, therefore, interchangeable. In practice, this means that Alpha assumes factor loadings to be the same for all items. Composite reliability does not assume this but takes into consideration the varying factor loadings of the items. Based on the internal consistency method, the Cronbach's alpha coefficient and CR values higher than 0.7 indicate that the questionnaire has good reliability (Peterson, 1994; Cho and Kim, 2015).

Table 3 reveals that the values obtained for Cronbach's alpha coefficient and CR were more than 0.7 , thereby confirming the construct reliability. Both convergent and discriminant validity are called the subtypes of construct validity. Their individual 
TABLE 2 | Information statistics of respondents.

\begin{tabular}{|c|c|c|c|}
\hline & Respondent information & Frequency & Relative frequency (\%) \\
\hline \multirow[t]{8}{*}{ Department } & Strategic management department & 25 & 10.92 \\
\hline & Low-carbon technology $R$ and $D$ department & 46 & 20.09 \\
\hline & Low-carbon product manufacturing department & 35 & 15.28 \\
\hline & International marketing department of low-carbon products & 39 & 17.03 \\
\hline & After-sales service department of low-carbon products & 21 & 9.17 \\
\hline & Environmental protection department & 24 & 10.48 \\
\hline & International business department & 19 & 8.30 \\
\hline & Investment and financing department & 20 & 8.73 \\
\hline \multirow[t]{3}{*}{ Management level } & Senior management & 67 & 29.26 \\
\hline & Middle manager & 72 & 31.44 \\
\hline & Grassroots management & 90 & 39.30 \\
\hline
\end{tabular}

Note: the total number of samples is 229.

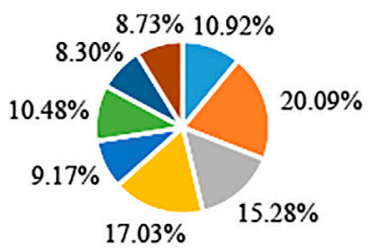

= Strategic management department

- Low carbon technology R \& D department

II Low carbon product manufacturing department

= International marketing department of low carbon products

- After sales service department of low carbon products

a Environmental protection department

- International business department

a Investment and financing department $\quad$ = Senior management $=$ Middle manager $=$ Grassroots management

FIGURE 4 | Department source and management level distribution of respondents.

function is insufficient to establish construct validity; while their combination proves the presence of construct validity. To test the measurement of the model's convergent validity and discriminant validity, the cross factor loading coefficient and average variance extracted (AVE) were applied to the SEM. Typically, factor loading coefficient values of variables that were more than 0.7 and AVE values more than 0.5 indicated that the measured variables could effectively describe the latent variables, thereby achieving a good convergent validity (Peterson, 1994; Cho and Kim, 2015). Additionally, if the factor loading coefficient of the latent variables for the measured indicators were higher than the other measured indicators and the AVE values were higher than all the correlation coefficient square of the other measured indicators of the latent variables, each variable in the model is considered to have good discriminant validity. As Table 3 exhibits, the factor loading coefficient of the measured variables and the AVE values in the proposed model were more than 0.7 and 0.5 , respectively, thereby showing that the latent variables have good convergent validity. Table 4 also reveals that the square root of AVE was higher than the correlation coefficient for all the other measured indicators of the latent variables. These results show that each variable in the research model has good discrimination validity.

\section{Collinearity Test}

The SEM method and hypothesis testing were analysed using SmartPLS 3.3 and SPSS 22 software. Table 5 displays the values for the factor loading for the reliability and validity analyses, thereby affirming that SEM can be performed to evaluate the influence path analyses. The variance inflation factor (VIF) value was computed to identify the presence of multicollinearity in the structural model. The maximum computed VIF value was 2.242 (Table 6), indicating that multicollinearity was not an issue at the structural model level (Wooldridge, 2003; Rafique et al., 2020).

\section{Evaluation of the Structural Model}

An effective sample size of 229 observations was evaluated for the proposed structural model, in which a significant correlation was observed between the unconsidered dimensions. The results of the standardized path coefficients between latent variables are represented as a diagram of the measurement results for the structural equation model. The value of the estimation method of PLS, $R^{2}$, was used to illustrate the ability of the structural equation model. These values explain the extent of the other latent variables in relation to the endogenous latent variables, thereby indicating the model's predictive ability. 
TABLE 3 | The reliability and validity test of the measurement model.

\begin{tabular}{|c|c|c|c|c|c|}
\hline Latent variables & Observed variables & Factor loadings & $\begin{array}{c}\text { Cronbach's alpha } \\
\text { coefficient }\end{array}$ & $\begin{array}{l}\text { Composite } \\
\text { reliability }\end{array}$ & $\begin{array}{c}\text { Average variance } \\
\text { extracted }\end{array}$ \\
\hline \multirow[t]{4}{*}{ Z1 } & Z11 & 0.702 & 0.805 & 0.873 & 0.634 \\
\hline & Z12 & 0.819 & & & \\
\hline & Z13 & 0.839 & & & \\
\hline & Z14 & 0.816 & & & \\
\hline \multirow[t]{4}{*}{ Z2 } & Z21 & 0.829 & 0.871 & 0.912 & 0.721 \\
\hline & Z22 & 0.855 & & & \\
\hline & Z23 & 0.865 & & & \\
\hline & Z24 & 0.846 & & & \\
\hline \multirow[t]{4}{*}{ Z3 } & Z31 & 0.780 & 0.821 & 0.882 & 0.651 \\
\hline & Z32 & 0.838 & & & \\
\hline & Z33 & 0.808 & & & \\
\hline & Z34 & 0.800 & & & \\
\hline \multirow[t]{4}{*}{ Z4 } & Z41 & 0.844 & 0.824 & 0.883 & 0.655 \\
\hline & Z42 & 0.845 & & & \\
\hline & Z43 & 0.816 & & & \\
\hline & Z44 & 0.727 & & & \\
\hline \multirow[t]{4}{*}{ Z5 } & Z51 & 0.729 & 0.790 & 0.864 & 0.614 \\
\hline & Z52 & 0.744 & & & \\
\hline & Z53 & 0.816 & & & \\
\hline & Z54 & 0.841 & & & \\
\hline \multirow[t]{4}{*}{ Z6 } & Z61 & 0.829 & 0.843 & 0.895 & 0.680 \\
\hline & Z62 & 0.863 & & & \\
\hline & Z63 & 0.789 & & & \\
\hline & Z64 & 0.816 & & & \\
\hline \multirow[t]{3}{*}{$\mathrm{Z7}$} & Z71 & 0.862 & 0.843 & 0.905 & 0.762 \\
\hline & Z72 & 0.878 & & & \\
\hline & Z73 & 0.877 & & & \\
\hline \multirow[t]{4}{*}{ Z8 } & Z81 & 0.704 & 0.756 & 0.846 & 0.580 \\
\hline & Z82 & 0.876 & & & \\
\hline & Z83 & 0.745 & & & \\
\hline & Z84 & 0.709 & & & \\
\hline
\end{tabular}

TABLE 4 | Correlation coefficient between latent variables.

\begin{tabular}{lcccccccc}
$\begin{array}{l}\text { Latent } \\
\text { variables }\end{array}$ & $\mathbf{Z 1}$ & $\mathbf{Z 2}$ & $\mathbf{Z 3}$ & $\mathbf{Z 4}$ & $\mathbf{Z 5}$ & $\mathbf{Z 6}$ & $\mathbf{Z 7}$ & $\mathbf{Z 8}$ \\
\hline Z1 & $\mathbf{0 . 7 9 6}$ & - & - & - & - & - & - & - \\
Z2 & 0.273 & $\mathbf{0 . 8 4 9}$ & - & - & - & - & - & - \\
Z3 & 0.538 & 0.326 & $\mathbf{0 . 8 0 7}$ & - & - & - & - & - \\
Z4 & 0.662 & 0.400 & 0.553 & $\mathbf{0 . 8 0 9}$ & - & - & - & - \\
Z5 & 0.385 & 0.429 & 0.333 & 0.271 & $\mathbf{0 . 7 8 4}$ & - & - & - \\
Z6 & 0.173 & 0.570 & 0.163 & 0.184 & 0.258 & $\mathbf{0 . 8 2 5}$ & - & - \\
Z7 & 0.421 & 0.499 & 0.435 & 0.463 & 0.371 & 0.496 & $\mathbf{0 . 8 7 3}$ & - \\
Z8 & 0.445 & 0.466 & 0.407 & 0.376 & 0.446 & 0.380 & 0.490 & $\mathbf{0 . 7 6 2}$
\end{tabular}

Note: The digital of the diagonal represents the square root of AVE

As demonstrated in Figure 5, the proposed model describes the variances for low-carbon technology innovation capability (52.5\%), low-carbon system innovation capability (26.2\%), low-carbon capital innovation capability (32.4\%), and low-carbon management innovation capability (36.4\%), thereby indicating that embedment in the GVC can predict the low-carbon innovation capability of manufacturing subsidiaries. The model also shows the variance for the sustainable competitive advantage (35.9\%), indicating that lowcarbon innovation capability can predict the sustainable competitive advantage of manufacturing subsidiaries.

\section{Hypotheses Testing}

The PLS method and bootstrapping method were used to test the direct effect and indirect effect of $\mathrm{H} 1$ to $\mathrm{H} 8$ by estimating the path coefficients, T statistic and $p$ value. The significance of the effect was tested at the significance levels of $0.1,0.05$, and 0.01 . Tables 7 , 8 exhibit the testing results.

\section{Direct Effect Testing}

As shown in Table 7, there is sufficient evidence from the results to indicate that the network management functions directly improve the low innovation capability of manufacturing subsidiaries. The path coefficients of the low-carbon technology innovation capability, low-carbon system innovation capability and low-carbon management innovation capability under the influence of embedment in global low-carbon $\mathrm{R}$ and $\mathrm{D}$ are $0.487,0.290$ and 0.212 , respectively. 
TABLE 5 | Crossover factor load factor between the metrics.

\begin{tabular}{|c|c|c|c|c|c|c|c|c|}
\hline & $\mathbf{Z 1}$ & Z2 & Z3 & Z4 & Z5 & Z6 & Z7 & Z8 \\
\hline Z11 & 0.702 & 0.202 & 0.340 & 0.463 & 0.338 & 0.134 & 0.266 & .380 \\
\hline Z12 & 0.819 & 0.166 & 0.482 & 0.509 & 0.292 & & & \\
\hline Z13 & 0.839 & 0.204 & 0.445 & 0.571 & 0.302 & & & \\
\hline Z14 & 0.816 & 0.291 & 0 & & & & & 372 \\
\hline Z21 & 0.251 & 0.829 & 0.273 & & & & & 0.387 \\
\hline Z22 & 0.236 & 0.855 & 0.235 & & 0.3 & & & \\
\hline Z23 & 0.247 & 0.865 & & & & & & \\
\hline Z24 & 0.191 & & & & & & & \\
\hline Z31 & 0.396 & 0.233 & & & & & & \\
\hline Z32 & 0.405 & 0.256 & 0.838 & 0.4 & 0.2 & & & \\
\hline Z33 & & & & & & & & \\
\hline Z34 & & & & & & & & 60 \\
\hline Z41 & 0.633 & 0.3 & 0.4 & 0.8 & 0.2 & & & \\
\hline Z42 & 0.5 & & & & & & & \\
\hline Z43 & & & & & & & & \\
\hline Z44 & & & & & & & & \\
\hline Z51 & 0.220 & 0.3 & 0.1 & 0.1 & 0.7 & 0.1 & & 0.274 \\
\hline Z52 & 0.331 & 0.291 & 0.2 & & & & & \\
\hline Z53 & & & & & & & & \\
\hline Z54 & & & & & & & & \\
\hline Z61 & 0.177 & & & & & & & \\
\hline Z62 & 0.139 & 0.492 & 0.138 & 0.1 & 0.210 & 0.863 & 0.4 & 0.339 \\
\hline Z63 & 0.084 & & & 0.099 & & & & 0.260 \\
\hline Z64 & 0.163 & 0.508 & 0.137 & 0.172 & 0.225 & 0.816 & 0.492 & 0.334 \\
\hline Z71 & 0.362 & 0.409 & 0.363 & 0.372 & 0.280 & 0.466 & 0.862 & 0.462 \\
\hline Z72 & 0.364 & 0.419 & 0.401 & 0.375 & 0.362 & 0.398 & 0.878 & 0.406 \\
\hline Z73 & 0.377 & 0.477 & 0.376 & 0.463 & 0.329 & 0.434 & 0.877 & 0.414 \\
\hline Z81 & 0.258 & & 0.263 & & 0.280 & 0.224 & 0.311 & 0.704 \\
\hline Z82 & 0.391 & & & & 0.376 & 0.340 & 0.477 & 0.876 \\
\hline Z83 & 0.340 & & 0.270 & & 0.398 & 0.249 & & 0.745 \\
\hline Z84 & 0.355 & 0.388 & 0.305 & 0.253 & 0.296 & 0.336 & 0.332 & 0.709 \\
\hline
\end{tabular}

At a significance level of 0.01 , the three path coefficients are significant, so, $\mathrm{H} 1 \mathrm{a}, \mathrm{H} 1 \mathrm{~b}$ and $\mathrm{H} 1 \mathrm{c}$ are accepted. These results indicate that embedment in global low carbon $\mathrm{R}$ and $\mathrm{D}$ exerts a positive impact on the improvement of the low-carbon innovation capability of manufacturing subsidiaries, and has the most significant effect on the improvement of the lowcarbon technology innovation ability. At the same time, embedment in global low-carbon $\mathrm{R}$ and $\mathrm{D}$ links can promote subsidiaries to innovate low-carbon management and the lowcarbon system around global $\mathrm{R}$ and $\mathrm{D}$ activities.

This study confirms the view that an increase in the GVC embedding position significantly improves green technology innovation efficiency, and there is industry heterogeneity characterized by pollution intensity and factor density (Hu et al., 2021). The acquisition of overseas high-tech enterprises and the establishment of overseas $\mathrm{R}$ and $\mathrm{D}$ centers are the main modes for Chinese manufacturing enterprise groups to participate in global $\mathrm{R}$ and $\mathrm{D}$ cooperation and improve their technological innovation ability. For example, after Haier Group set up its R and D center in the United States, it improved the technological innovation ability of energy saving and consumption reduction of household appliances.

Still in Table 7, the path coefficients of the low-carbon technology innovation capability, low-carbon system innovation capability, low-carbon capital innovation capability, and low-carbon management innovation
TABLE 6 | VIF value.

\begin{tabular}{lccccc}
\hline Observed variables & VIF & $\mathbf{1 / V I F}$ & Observed variables & VIF & $\mathbf{1 / V I F}$ \\
\hline Z11 & 1.364 & 0.733 & $Z 51$ & 1.556 & 0.643 \\
Z12 & 1.935 & 0.517 & $Z 52$ & 1.404 & 0.712 \\
Z13 & 2.022 & 0.495 & $Z 53$ & 1.773 & 0.564 \\
Z14 & 1.711 & 0.584 & $Z 54$ & 2.020 & 0.495 \\
Z21 & 1.960 & 0.510 & $Z 61$ & 1.944 & 0.514 \\
Z22 & 2.163 & 0.462 & $Z 62$ & 2.153 & 0.465 \\
Z23 & 2.242 & 0.446 & $Z 63$ & 1.740 & 0.575 \\
Z24 & 2.102 & 0.476 & $Z 64$ & 1.724 & 0.580 \\
Z31 & 1.641 & 0.609 & $Z 71$ & 1.895 & 0.528 \\
Z32 & 2.022 & 0.494 & $Z 72$ & 2.125 & 0.471 \\
Z33 & 1.723 & 0.580 & $Z 73$ & 2.051 & 0.488 \\
Z34 & 1.639 & 0.610 & $Z 81$ & 1.393 & 0.718 \\
Z41 & 1.804 & 0.554 & $Z 82$ & 2.094 & 0.478 \\
Z42 & 2.067 & 0.484 & $Z 83$ & 1.611 & 0.621 \\
Z43 & 1.897 & 0.527 & $Z 84$ & 1.430 & 0.699 \\
Z44 & 1.447 & 0.691 & & & \\
\hline
\end{tabular}

capability under the influence of embedment in global low carbon manufacturing are $0.193,0.350,0.570$ and 0.376 respectively. At a significance level of 0.01 , the test results support $\mathrm{H} 2 \mathrm{a}, \mathrm{H} 2 \mathrm{~b}, \mathrm{H} 2 \mathrm{c}$, and $\mathrm{H} 2 \mathrm{~d}$, which shows that embedment in global low-carbon manufacturing links can directly promote the improvement of the low-carbon innovation capability of Chinese subsidiaries. Building factories and producing low-carbon products worldwide, Chinese enterprise groups need to make great innovations in their investment and financing modes and scale. By obtaining domestic financing and attracting external investment, their capital innovation ability will be greatly improved. In this sense, participating in global manufacturing has the most significant effect on the improvement of the low-carbon capital innovation ability of Chinese manufacturing subsidiaries.

For H3, engagement in global-low carbon marketing exerts a positively-oriented impact on the improvement of the lowcarbon innovation capability in manufacturing subsidiaries. The direct effect of embedment in global low-carbon marketing on the low-carbon technology innovation capability and low-carbon management innovation capability are 0.228 and 0.119 respectively. At a significance level of $0.01, \mathrm{H} 3 \mathrm{a}$, and $\mathrm{H} 3 \mathrm{~b}$ passed the test. $\mathrm{Li}$ et al. (2020) found that establishing the GVC can improve the export technical complexity of the equipment-manufacturing industry, and with the promotion of domestic openness and industry $\mathrm{R}$ and $\mathrm{D}$ investment conditions, this improvement is likely to be healthy. Through interviews with executives of Chinese business groups and its subsidiaries, it was found that in order to improve the companie's overseas low carbon products and technology marketing activities, the companies were strengthening their marketing management innovations. The test results are in line with reality.

The direct effect of the low-carbon technology innovation capability, low-carbon system innovation capability, lowcarbon capital innovation capability, and low-carbon management innovation capability on sustainable competitive advantage are $0.165,0.274,0.165$, and 0.230 


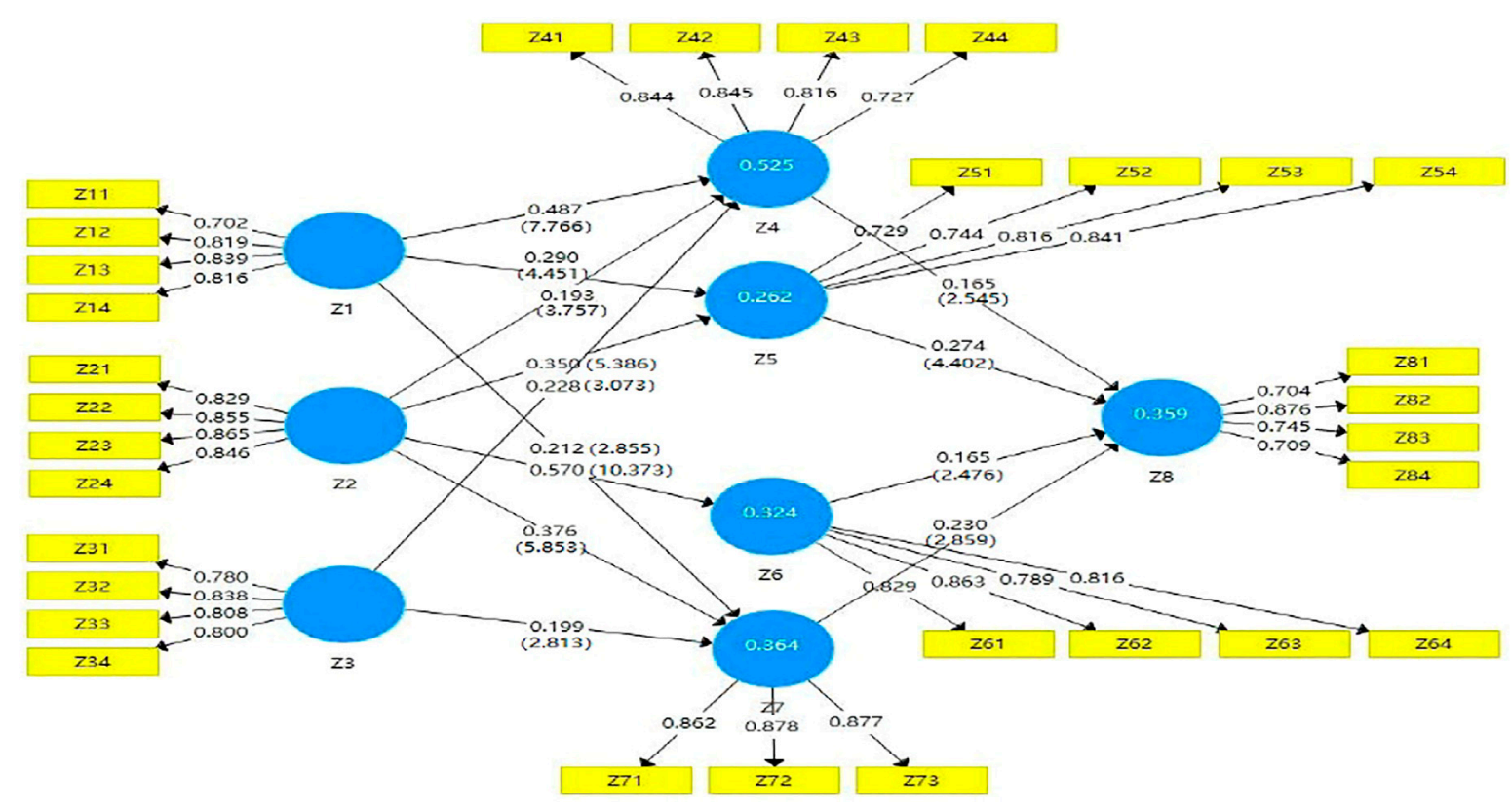

FIGURE 5 | PLS-SEM estimation results.

TABLE 7 | Path coefficient with mediating variables and significance test results.

\begin{tabular}{lcccc}
\hline Paths & $\begin{array}{c}\text { Paths } \\
\text { beta }(\boldsymbol{\beta}) \text { coefficient }\end{array}$ & T Statistic & $\boldsymbol{p}$ Value & Test results \\
\hline$Z 1 \rightarrow Z 4$ & 0.487 & 7.844 & 0.000 & accepted \\
$Z 1 \rightarrow Z 5$ & 0.290 & 4.522 & 0.000 & accepted \\
$Z 1 \rightarrow Z 7$ & 0.212 & 2.920 & 0.004 & accepted \\
$Z 2 \rightarrow Z 4$ & 0.193 & 3.759 & 0.000 & accepted \\
$Z 2 \rightarrow Z 5$ & 0.350 & 5.471 & 0.000 & accepted \\
$Z 2 \rightarrow Z 6$ & 0.570 & 10.410 & 0.000 & accepted \\
$Z 2 \rightarrow Z 7$ & 0.376 & 5.785 & 0.000 & accepted \\
$Z 3 \rightarrow Z 4$ & 0.228 & 3.082 & 0.002 & accepted \\
$Z 3 \rightarrow Z 7$ & 0.199 & 2.833 & 0.005 & accepted \\
$Z 4 \rightarrow Z 8$ & 0.165 & 2.567 & 0.010 & accepted \\
$Z 5 \rightarrow Z 8$ & 0.274 & 4.393 & 0.000 & accepted \\
$Z 6 \rightarrow Z 8$ & 0.165 & 2.453 & 0.014 & accepted \\
$Z 7 \rightarrow Z 8$ & 0.230 & 2.897 & 0.004 & accepted \\
$Z 1 \rightarrow Z 8$ & 0.208 & 4.810 & 0.000 & accepted \\
$Z 2 \rightarrow Z 8$ & 0.308 & 7.830 & 0.000 & accepted \\
$Z 3 \rightarrow Z 8$ & 0.083 & 2.926 & 0.003 & accepted \\
$Z 1 \rightarrow Z 4 \rightarrow Z 8$ & 0.080 & 2.293 & 0.022 & accepted \\
$Z 2 \rightarrow Z 4 \rightarrow Z 8$ & 0.032 & 2.164 & 0.031 & accepted \\
$Z 3 \rightarrow Z 4 \rightarrow Z 8$ & 0.038 & 1.953 & 0.051 & accepted \\
$Z 1 \rightarrow Z 5 \rightarrow Z 8$ & 0.079 & 3.301 & 0.001 & accepted \\
$Z 2 \rightarrow Z 5 \rightarrow Z 8$ & 0.096 & 2.949 & 0.003 & accepted \\
$Z 2 \rightarrow Z 6 \rightarrow Z 8$ & 0.094 & 2.278 & 0.023 & accepted \\
$Z 1 \rightarrow Z 7 \rightarrow Z 8$ & 0.049 & 2.024 & 0.043 & accepted \\
$Z 2 \rightarrow Z 7 \rightarrow Z 8$ & 0.087 & 2.510 & 0.012 & accepted \\
$Z 3 \rightarrow Z 7 \rightarrow Z 8$ & 0.046 & 1.866 & 0.062 & accepted \\
& & & &
\end{tabular}

respectively. At a significance level of $0.05, \mathrm{H} 4$ and $\mathrm{H} 6$ are accepted. At a significance level of $0.01, \mathrm{H} 5$ and $\mathrm{H} 7$ are accepted. All four hypotheses passed the significance test. The test results suggest a positive association between the
TABLE 8 | Path coefficient excluding mediating variables and significance test result.

\begin{tabular}{lcccc} 
Paths & $\begin{array}{c}\text { Paths } \\
\text { beta }(\boldsymbol{\beta}) \text { coefficient }\end{array}$ & T Statistic & $\boldsymbol{p}$ Value & Test results \\
\hline $\mathrm{Z} 1 \rightarrow$ Z8 & 0.277 & 3.764 & 0.000 & \\
$Z 2 \rightarrow Z 8$ & 0.347 & 5.846 & 0.000 & accepted \\
$Z 3 \rightarrow Z 8$ & 0.148 & 1.865 & 0.062 & accepted \\
& & & &
\end{tabular}

low-carbon innovation capability and the sustainable competitive advantage of manufacturing subsidiaries. The management of a subsidiary can purposely follow a strategy to move to such a position in the multi-business MNE as a GVC joint coordinator for a product category. This strategy is likely to attain this position by leveraging its comprehensive innovation abilities to assume more effective control on the business group's GVC governance. Within the MNE, this position of higher eminence for the subsidiary expands its internal advantage (Ryan et al., 2020).

\section{Mediating Effect Testing}

The step-by-step regression beta coefficient method, involving three steps, was used to test the mediating effect. The first step was to test the significance of the overall effect of exogenous latent variables on endogenous latent variables. The second step was to test the significance of the direct effect of exogenous latent variables on intermediary endogenous latent variables and of intermediary exogenous latent variables on exogenous latent variables. The third step was to test whether the coefficient or significance of the main effect is reduced after adding the mediating endogenous latent variables (Baron and Kenny, 1986). 
Firstly, we tested the total effect of embedment in the GVC on the sustainable competitive advantage in the original model by deleting the mediating variables, building a new model, and testing the coefficient and significance. In Table 8, the direct effect regression beta coefficients of embedment in global low-carbon $\mathrm{R}$ and $\mathrm{D}$, embedment in global low-carbon manufacturing and embedment in global low-carbon marketing on the sustainable competitive advantage for Chinese manufacturing subsidiaries are $0.277,0.347$, and 0.148 . At a significance level of 0.01 , embedment in global low-carbon $\mathrm{R}$ and $\mathrm{D}$ and embedment in global lowcarbon manufacturing have significant impacts on the sustainable competitive advantage. At a significance level of 0.1, embedment in global low-carbon marketing has a significant impact on the sustainable competitive advantage. The outbreak of global COVID-19 is both a challenge and an opportunity for China's manufacturing industry. However, China's effective control measures against COVID-19 have played a catalytic role in China's commodity exports, which helps Chinese subsidiaries to establish or enhance their sustainable competitive advantages globally. For example, an electronics company affiliated with Haier Group took the opportunity to expand the global sales of low-energy household appliances and expand the global market share. These study findings tally with the real situation of the global $\mathrm{R}$ and $\mathrm{D}$, production and marketing of Chinese subsidiaries.

Secondly, we tested the significance of the direct effect of embedment in the GVC on the low-carbon innovation capability, and low-carbon innovation capability on the sustainable competitive advantage. In the above results, the significance of these two effects has been verified.

Thirdly, we tested whether the coefficient or significance of the main effect is reduced after adding the mediating variables. In Table 7 , at a significance level of 0.01 , the indirect path coefficient of embedment in global low-carbon $\mathrm{R}$ and $\mathrm{D}$ on the sustainable competitive advantage is 0.208 , lower than the main effect path coefficient (0.277) excluding mediating variables, the low-carbon innovation capability, which indicates that the mediating effect is significant, H8a is accepted. The result indicates that the lowcarbon innovation capability partially mediates the relation between embedment in global low carbon $\mathrm{R}$ and $\mathrm{D}$ and the sustainable competitive advantage. For $\mathrm{H} 8 \mathrm{~b}$, at a significance level of 0.01 , the indirect path coefficient of embedment in global lowcarbon manufacturing on the sustainable competitive advantage is 0.308 , and the mediating effect is significant, therefore $\mathrm{H} 8 \mathrm{~b}$ is accepted. The indirect path coefficient is lower than the main effect path coefficient (0.347) excluding mediating variables, which indicates that the low-carbon innovation capability partially mediates the relation between global low-carbon manufacturing and the sustainable competitive advantage. For $\mathrm{H} 8 \mathrm{c}$, at a significance level of 0.01 , the indirect path coefficient of embedment in global low-carbon marketing on the sustainable competitive advantage is 0.083 , the mediating effect is significant, lower than the main effect path coefficient (0.148) excluding mediating variables, which reveals that the low-carbon innovation capability partially mediates the relation between global-low carbon marketing and the sustainable competitive advantage, hence $\mathrm{H} 8 \mathrm{c}$ is accepted. Overall, the low-carbon innovation capabilities partially mediate between embedment in the GVC and the sustainable competitive advantage. In other words, the role of embedment in the GVC in improving the sustainable competitive advantage of Chinese Enterprise Group's subsidiaries is partly realized through the improvement of their own low-carbon innovation ability. Park (2021) showed that the establishment of local innovation has played a certain role in the participation of African countries in global logistics marketing and the establishment of a competitive advantage. Our research conclusion further confirms this view.

About specific mediating effects, in Table 7, firstly, the three indirect path coefficients of the low-carbon technology innovation capability are $0.080,0.032$, and 0.038 , at a significance level of 0.1 , where the mediating effect of the low carbon technology innovation capability is significant. Secondly, the two indirect path coefficients of the low-carbon system innovation capability are 0.079 and 0.096 , at a significance level of 0.01 , where the mediating effect of the lowcarbon system innovation capability is significant. Thirdly, the indirect path coefficients of the low-carbon capital innovation capability are 0.094 , at a significance level of 0.01 , where the mediating effect of the low-carbon capital innovation capability between embedment in global low carbon manufacturing and the sustainable competitive advantage is significant. Fourthly, the three indirect path coefficients of the low-carbon technology innovation capability are $0.049,0.087$, and 0.046 , at a significance level of 0.1 , where the mediating effect of the low-carbon management innovation capability between embedment in the GVC and the sustainable competitive advantage is significant.

\section{CONCLUSION}

The major objective of this paper was to investigate how embedment in the GVC in manufacturing subsidiaries can be used to foster a sustainable competitive advantage. In light of the available literature, we hypothesized that embedment in the GVC contributes to the improvement of the low-carbon innovation capability in Chinese manufacturing subsidiaries. Additionally, the low-carbon innovation capability fostered a sustainable competitive advantage and the impact of embedment in the GVC on the sustainable competitive advantage is mediated by the low-carbon innovation capability improvement. Three significant findings were identified based on the results of this empirical study. Firstly, this study provides sufficient evidence to support the notion that embedment in the GVC significantly enhances the low-carbon innovation capability through global cooperation. In a study by (Landsperger and Spieth, 2011), the authors noted that the successful embedment of global low-carbon $\mathrm{R}$ and $\mathrm{D}$, manufacturing, and marketing led to an increase in the low-carbon innovation capabilities. Secondly, the results indicate that an improvement in the low-carbon innovation capability has a considerable impact on the fostering of a sustainable competitive advantage and support for low-carbon technology, system, capital, and management innovation capability, as indicated by Uyarra et al. (2016) and Sears, (2017). Thirdly, the results obtained in this study confirm that the low-carbon innovation capabilities 
significantly mediated the positive effect of embedment in the GVC on the sustainable competitive advantage of Chinese manufacturing subsidiaries.

The outcomes of this study provide several significant contributions to the existing literature. Firstly, this study focuses on global low-carbon $\mathrm{R}$ and $\mathrm{D}$, manufacturing and marketing in the GVC, thereby expanding the scope of the GVC theory beyond lowcarbon initiatives. Secondly, innovation capacity is an important resource for enterprises, especially for manufacturing subsidiaries. The resource based theory suggests that sustainable competitive advantage resources are heterogeneous and it is difficult for them to flow freely, thereby representing the key determinants of firm value (Wernerfelt, 1984). Our results support this theory from the lowcarbon technology standpoint and institutional, capital and managerial innovation capabilities, where the theory of innovation is further extended beyond the low-carbon innovation view point. Thirdly, Potter's competitive advantage theory proposes a model of international competition that emphasizes four country specific determinants and two types of external forces. This study verified the importance of three external international resources and four internal innovation resources for the sustainable competitive advantage of manufacturing subsidiaries.

This study also highlights some important managerial implications that should be addressed. The manufacturing subsidiarie's capability to achieve a sustainable competitive advantage represents a significant asset when developing innovations. The findings reveal that a thorough evaluation of the company's innovation resources to identify potential positions for the GVC is highly advisable. Therefore, companies should continuously identify high-quality resources from the GVC and discover ways of integrating internal and external carbon innovation resources to form innovation capability. Besides, companies should also analyze the cost issues of transforming the low-carbon innovation capability into a competitive advantage and evaluate the consistency of their low-carbon innovation strategy with the parent company. The findings can be used to facilitate manufacturing subsidiaries in increasing their sustainable competitive advantage and consequently supporting their capability to utilize external knowledge and insights from embedment in the GVC. Hence, it is evident that low-carbon innovation resources play the role of a sustainable competitive advantage for manufacturing subsidiaries.

Nevertheless, this study has certain limitations. This study did not utilize the number of patents as a measurement of innovation because of their non-availability. Further research should be performed to recognize the effects of innovation on the companie's low-carbon technology innovation capability as there is a significant gap in existing literature. Besides, the association between the global innovation activities of business

\section{REFERENCES}

Balachandra, R., and Friar, J. H. (1997). Factors for Success in R\&D Projects and New Product Innovation: a Contextual Framework. IEEE Trans. Eng. Manage. 44, 276-287. doi:10.1109/17.618169 groups and the low-carbon innovation performance of subsidiaries should be investigated. This study serves as an initial platform for discovering the impact of embedment in the GVC on a sustainable competitive advantage, and can be utilized to promote further research efforts using cases from other organizational domains and countries. Survey studies based on specific key indicators may be designed for future research.

\section{DATA AVAILABILITY STATEMENT}

The raw data supporting the conclusions of this article will be made available by the authors, without undue reservation.

\section{AUTHOR CONTRIBUTIONS}

SD: Methodology, Data collection, Results and discussion. MR: Introduction writing, Literature review, Reviewing. MH-S: Abstract, Methodology, Software, Results. AL: Results and discussion, Reviewing. CZ: Conceptualization, Concluding Remarks and Implications, Supervision.

\section{FUNDING}

The present study is conducted under the umbrella of the National Natural Science Foundation of China Research Project on the relationship between the characteristics of enterprise group internal network and the technology innovation of subsidiary company No.71672102. MH-S is thankful to the Ministry of Science and Higher Education in Poland for financial support to carry out this research.

\section{ACKNOWLEDGMENTS}

The corresponding author would like to thank the International Postdoctoral Exchange Program, Shandong University, under the China International Postdoctoral Exchange Fellowship Program for their financial support.

\section{SUPPLEMENTARY MATERIAL}

The Supplementary Material for this article can be found online at: https:/www.frontiersin.org/articles/10.3389/fenvs.2021.779295/ full\#supplementary-material

Barney, J. (1991). Firm Resources and Sustained Competitive Advantage. J. Management. 17, 99-120. doi:10.1177/014920639101700108

Baron, R. M., and Kenny, D. A. (1986). The Moderator-Mediator Variable Distinction in Social Psychological Research: Conceptual, Strategic, and Statistical Considerations. J. Personal. Soc. Psychol. 51, 1173-1182. doi:10.1037/0022-3514.51.6.1173 
Bi, K., Huang, P., and Wang, X. (2016). Innovation Performance and Influencing Factors of Low-Carbon Technological Innovation Under the Global Value Chain: A Case of Chinese Manufacturing Industry. Technol. Forecast. Soc. Change. 111, 275-284. doi:10.1016/j.techfore.2016.07.024

Bi, K., Huang, P., and Ye, H. (2015). Risk Identification, Evaluation and Response of Low-Carbon Technological Innovation Under the Global Value Chain: A Case of the Chinese Manufacturing Industry. Technol. Forecast. Soc. Change. 100, 238-248. doi:10.1016/j.techfore.2015.07.005

Binz, C., and Truffer, B. (2017). Global Innovation Systems-A Conceptual Framework for Innovation Dynamics in Transnational Contexts. Res. Pol. 46, 1284-1298. doi:10.1016/j.respol.2017.05.012

Castellani, D., and Zanfei, A. (2007). Internationalisation, Innovation and Productivity: How Do Firms Differ in Italy? World Economy. 30, 156-176. doi:10.1111/j.1467-9701.2007.00875.x

Centobelli, P., Cerchione, R., and Esposito, E. (2018). Environmental Sustainability and Energy-Efficient Supply Chain Management: A Review of Research Trends and Proposed Guidelines. Energies. 11, 275. doi:10.3390/en11020275

Chahal, H., Gupta, M., Bhan, N., and Cheng, T. C. E. (2020). Operations Management Research Grounded in the Resource-Based View: A MetaAnalysis. Int. J. Prod. Econ. 230, 107805. doi:10.1016/j.ijpe.2020.107805

Chen, H. H., Chen, S., and Lan, Y. (2016). Attaining a Sustainable Competitive Advantage in the Smart Grid Industry of China Using Suitable Open Innovation Intermediaries. Renew. Sustainable Energ. Rev. 62, 1083-1091. doi:10.1016/j.rser.2016.03.008

Cho, E., and Kim, S. (2015). Cronbach's Coefficient Alpha. Organizational Res. Methods. 18, 207-230. doi:10.1177/1094428114555994

Defraigne, J.-C. (2017). Chinese Outward Direct Investments in Europe and the Control of the Global Value Chain. Asia Eur. J. 15, 213-228. doi:10.1007/ s10308-017-0476-3

Dierickx, I., and Cool, K. (1989). Asset Stock Accumulation and Sustainability of Competitive Advantage. Management Sci. 35, 1504-1511. doi:10.1287/ mnsc.35.12.1504

Doğan, B., Driha, O. M., Balsalobre Lorente, D., and Shahzad, U. (2020). The Mitigating Effects of Economic Complexity and Renewable Energy on Carbon Emissions in Developed Countries. Sustainable Development. 29, 1-12. doi:10.1002/sd.2125

Ferraz, D., Costa, N. J. d., Fernandes, B., Silva, E. P., Marques, P. H. M., Moralles, H. F., et al. (2018). Analysis of Absorptive Capacity and Foreign Direct Investment in the Productivity of Brazilian Municipalities. Prod. 28, e20180050. doi:10.1590/0103-6513.20180050

Ferraz, D., Falguera, F. P. S., Mariano, E. B., and Hartmann, D. (2021). Linking Economic Complexity, Diversification, and Industrial Policy With Sustainable Development: A Structured Literature Review. Sustainability. 13, 1265-1329. doi:10.3390/su13031265

Fornell, C., and Larcker, D. F. (1981). Structural Equation Models with Unobservable Variables and Measurement Error: Algebra and Statistics. J. Marketing Res. 18, 382. doi:10.2307/3150980

Galbraith, J. R. (1982). Designing the Innovating Organization. Organizational Dyn. 10, 5-25. doi:10.1016/0090-2616(82)90033-X

Hall, L. A., and Bagchi-Sen, S. (2002). A Study of R\&D, Innovation, and Business Performance in the Canadian Biotechnology Industry. Technovation. 22, 231-244. doi:10.1016/S0166-4972(01)00016-5

Higgins, A., Paevere, P., Gardner, J., and Quezada, G. (2012). Combining Choice Modelling and Multi-Criteria Analysis for Technology Diffusion: An Application to the Uptake of Electric Vehicles. Technol. Forecast. Soc. Change. 79, 1399-1412. doi:10.1016/j.techfore.2012.04.008

Hirsch-Kreinsen, H. (2011). Financial Market and Technological Innovation. Industry and Innovation. 18, 351-368. doi:10.1080/13662716.2011.573954

Hu, D., Jiao, J., Tang, Y., Han, X., and Sun, H. (2021). The Effect of Global Value Chain Position on Green Technology Innovation Efficiency: From the Perspective of Environmental Regulation. Ecol. Indicators. 121, 107195. doi:10.1016/j.ecolind.2020.107195

Kumar, A., and Motwani, J. (1995). A Methodology for Assessing Time-based Competitive Advantage of Manufacturing Firms. Int. Jrnl Op Prod. Mnagemnt. 15, 36-53. doi:10.1108/01443579510080409

Lai, X., Liu, J., Shi, Q., Georgiev, G., and Wu, G. (2017). Driving Forces for Low Carbon Technology Innovation in the Building Industry: A Critical Review. Renew. Sustainable Energ. Rev. 74, 299-315. doi:10.1016/j.rser.2017.02.044
Landsperger, J., and Spieth, P. (2011). Managing Innovation Networks in the Industrial Goods Sector. Int. J. Innov. Mgt. 15, 1209-1241. doi:10.1142/ S1363919611003714

Li, S., Ragu-Nathan, B., Ragu-Nathan, T. S., and Subba Rao, S. (2006). The Impact of Supply Chain Management Practices on Competitive Advantage and Organizational Performance. Omega. 34, 107-124. doi:10.1016/j.omega.2004.08.002

Li, T., Zhang, R., Zhao, S., and Liu, B. (2019). Low Carbon Strategy Analysis Under Revenue-Sharing and Cost-Sharing Contracts. J. Clean. Prod. 212, 1462-1477. doi:10.1016/j.jclepro.2018.11.282

Li, Y., Zhang, H., Liu, Y., and Huang, Q. (2020). Impact of Embedded Global Value Chain on Technical Complexity of Industry Export-An Empirical Study Based on China's Equipment Manufacturing Industry Panel. Sustainability. 12, 2694. doi:10.3390/su12072694

Liu, Q., Liu, A., Li, Y., Xu, W., Liu, J., Chen, G., et al. (2017). Intelligent Condition Perception Network Towards Sustainable Manufacturing Capability for Manufacturing Systems. Int. J. Manuf. Res. 12, 287-304. doi:10.1504/ IJMR.2017.086172

Masri, H. A., and Jaaron, A. A. M. (2017). Assessing green Human Resources Management Practices in Palestinian Manufacturing Context: An Empirical Study. J. Clean. Prod. 143, 474-489. doi:10.1016/j.jclepro.2016.12.087

Mayer, F. W., and Phillips, N. (2017). Outsourcing Governance: States and the Politics of a 'global Value Chain World'. New Polit. Economy. 22, 134-152. doi:10.1080/13563467.2016.1273341

Mentel, U., and Hajduk-Stelmachowicz, M. (2020). Does Standardization Have an Impact on Innovation Activity in Different Countries? Probl. Perspect. Management. 18 (4), 486-503. doi:10.21511/ppm.18(4).2020.39

Morrison, A., Pietrobelli, C., and Rabellotti, R. (2008). Global Value Chains and Technological Capabilities: A Framework to Study Learning and Innovation in Developing Countries. Oxford Development Stud. 36, 39-58. doi:10.1080/ 13600810701848144

Ngah, R., Abd Wahab, I., and Salleh, Z. (2015). The Sustainable Competitive Advantage of Small and Medium Entreprises (SMEs) With Intellectual Capital, Knowledge Management and Innovative Intelligence: Building a Conceptual Framework. Adv. Sci. Lett. 21, 1325-1328. doi:10.1166/asl.2015.6018

Nishitani, K., and Kokubu, K. (2012). Why Does the Reduction of Greenhouse Gas Emissions Enhance Firm Value? the Case of Japanese Manufacturing Firms. Bus. Strat. Env. 21, 517-529. doi:10.1002/bse.734

Ockwell, D., Sagar, A., and de Coninck, H. (2015). Collaborative Research and Development (R\&D) for Climate Technology Transfer and Uptake in Developing Countries: Towards a Needs Driven Approach. Climatic Change. 131, 401-415. doi:10.1007/s10584-014-1123-2

Pacana, A., Czerwińska, K., Bednárová, L., and Džuková, J. (2020). Analysis of a Practical Approach to the Concept of Sustainable Development in a Manufacturing Company in the Automotive Sector. Waste Forum. 3, 151-160.

Pananond, P. (2013). Where Do We Go from Here? Globalizing Subsidiaries Moving up the Value Chain. J. Int. Management. 19, 207-219. doi:10.1016/ j.intman.2013.03.002

Peterson, R. A. (1994). A Meta-Analysis of Cronbach's Coefficient Alpha. J. Consum. Res. 21, 381. doi:10.1086/209405

Pietrobelli, C., and Rabellotti, R. (2011). Global Value Chains Meet Innovation Systems: Are There Learning Opportunities for Developing Countries? World Development. 39, 1261-1269. doi:10.1016/j.worlddev.2010.05.013

Polloni-Silva, E., Ferraz, D., Camioto, F. d. C., Rebelatto, D. A. D. N., and Moralles, H. F. (2021). Environmental Kuznets Curve and the Pollution-Halo/haven Hypotheses: An Investigation in Brazilian Municipalities. Sustainability. 13, 4114. doi:10.3390/su13084114

Qu, C., Shao, J., and Cheng, Z. (2020). Can Embedding in Global Value Chain Drive Green Growth in China's Manufacturing Industry? J. Clean. Prod. 268 121962. doi:10.1016/j.jclepro.2020.121962

Rafique, M. Z., Li, Y., Larik, A. R., and Monaheng, M. P. (2020). The Effects of FDI, Technological Innovation, and Financial Development on CO2 Emissions: Evidence from the BRICS Countries. Environ. Sci. Pollut. Res. 27, 23899-23913. doi:10.1007/s11356-020-08715-2

Ryan, P., Buciuni, G., Giblin, M., and Andersson, U. (2020). Subsidiary Upgrading and Global Value Chain Governance in the Multinational Enterprise. Glob. Strategy J. 10, 496-519. doi:10.1002/gsj.1387

Safari, A., and Saleh, A. S. (2020). Key Determinants of SME's export Performance: a Resource-Based View and Contingency Theory Approach 
Using Potential Mediators. J. Bus. Ind. Mark. 35, 635-654. doi:10.1108/JBIM11-2018-0324

Sears, J. B. (2017). When Are Acquired Technological Capabilities Complements Rather Than Substitutes? A Study on Value Creation. J. Business Res. 78, 33-42. doi:10.1016/j.jbusres.2017.04.021

Shahzad, U., Fareed, Z., Shahzad, F., and Shahzad, K. (2021). Investigating the Nexus Between Economic Complexity, Energy Consumption and Ecological Footprint for the United States: New Insights From Quantile Methods. J. Clean. Prod. 279, 123806. doi:10.1016/j.jclepro.2020.123806

Shahzad, U., Ferraz, D., Doğan, B., and Aparecida do Nascimento Rebelatto, D. (2020). Export Product Diversification and CO2 Emissions: Contextual Evidences from Developing and Developed Economies. J. Clean. Prod. 276, 124146. doi:10.1016/j.jclepro.2020.124146

Shahzad, U., Ferraz, D., Nguyen, H.-H., and Cui, L. (2022). Investigating the Spill Overs and Connectedness Between Financial Globalization, High-Tech Industries and Environmental Footprints: Fresh Evidence in Context of China. Technol. Forecast. Soc. Change. 174, 121205. doi:10.1016/ J.TECHFORE.2021.121205

Shibin, K. T., Dubey, R., Gunasekaran, A., Hazen, B., Roubaud, D., Gupta, S., et al. (2020). Examining Sustainable Supply Chain Management of SMEs Using Resource Based View and Institutional Theory. Ann. Oper. Res. 290, 301-326. doi:10.1007/s10479-017-2706-x

Siwiec, D., and Pacana, A. (2021). Model Supporting Development Decisions by Considering Qualitative-Environmental Aspects. Sustainability. 13 (16), 9067. doi:10.3390/su13169067

Stead, J. G., and Stead, E. (2000). Eco-Enterprise Strategy: Standing for Sustainability. J. Bus. Ethics. 24, 313-329. doi:10.1023/A:1006188725928

Sun, C., Li, Z., Ma, T., and He, R. (2019a). Carbon Efficiency and International Specialization Position: Evidence From Global Value Chain Position index of Manufacture. Energy Policy. 128, 235-242. doi:10.1016/j.enpol.2018.12.058

Sun, H., Edziah, B. K., Sun, C., and Kporsu, A. K. (2019b). Institutional Quality, Green Innovation and Energy Efficiency. Energy Policy. 135, 111002. doi:10.1016/j.enpol.2019.111002

Tang, G., Chen, Y., Jiang, Y., Paillé, P., and Jia, J. (2018). Green Human Resource Management Practices: Scale Development and Validity. Asia Pac. J. Hum. Resour. 56, 31-55. doi:10.1111/1744-7941.12147

Tian, X., Bai, F., Jia, J., Liu, Y., and Shi, F. (2019). Realizing Low-Carbon Development in a Developing and Industrializing Region: Impacts of Industrial Structure Change on $\mathrm{CO} 2$ Emissions in Southwest China. J. Environ. Manage. 233, 728-738. doi:10.1016/j.jenvman.2018.11.078

Tian, Y., Xiong, S., Ma, X., and Ji, J. (2018). Structural Path Decomposition of Carbon Emission: A Study of China's Manufacturing Industry. J. Clean. Prod. 193, 563-574. doi:10.1016/j.jclepro.2018.05.047

Timmerman, J., Hennen, M., Bardow, A., Lodewijks, P., Vandevelde, L., Van Eetvelde, G., et al. (2017). Towards Low Carbon Business Park Energy Systems: A Holistic Techno-Economic Optimisation Model. Energy. 125, 747-770. doi:10.1016/j.energy.2017.02.081

Tiwari, M. K., Chang, P.-C., and Choudhary, A. (2015). Carbon-Efficient Production, Supply Chains and Logistics. Int. J. Prod. Econ. 164, 193-196. doi:10.1016/j.ijpe.2015.02.008

Tridech, S., and Cheng, K. (2011). Low Carbon Manufacturing: Characterisation, Theoretical Models and Implementation. Int. J. Manuf. Res. 6, 110-121. doi:10.1504/IJMR.2011.040006
Uyarra, E., Shapira, P., and Harding, A. (2016). Low Carbon Innovation and Enterprise Growth in the UK: Challenges of a Place-Blind Policy Mix. Technol. Forecast. Soc. Change. 103, 264-272. doi:10.1016/ j.techfore.2015.10.008

Varadarajan, R. (2017). Innovating for Sustainability: a Framework for Sustainable Innovations and a Model of Sustainable Innovations Orientation. J. Acad. Mark. Sci. 45, 14-36. doi:10.1007/s11747-015-0461-6

Wang, Z., Ben Jebli, M., Madaleno, M., Doğan, B., and Shahzad, U. (2021). Does export Product Quality and Renewable Energy Induce Carbon Dioxide Emissions: Evidence From Leading Complex and Renewable Energy Economies. Renew. Energ. 171, 360-370. doi:10.1016/j.renene.2021.02.066

Weerawardena, J. (2003). The Role of Marketing Capability in Innovation-Based Competitive Strategy. J. Strateg. Marketing. 11, 15-35. doi:10.1080/ 0965254032000096766

Wernerfelt, B. (1984). A Resource-Based View of the Firm. Strat. Mgmt. J. 5, 171-180. doi:10.1002/smj.4250050207

Wooldridge, J. M. (2003). Introductory Econometrics: A Modern Approach. Atrium Way Nashville, TN: South-Western College Publishing.

Wu, D. D., Kefan, X., Hua, L., Shi, Z., and Olson, D. L. (2010). Modeling Technological Innovation Risks of an Entrepreneurial Team Using System Dynamics: An Agent-Based Perspective. Technol. Forecast. Soc. Change. 77, 857-869. doi:10.1016/j.techfore.2010.01.015

Yu, C., and Luo, Z. (2018). What Are China's Real Gains Within Global Value Chains? Measuring Domestic Value Added in China's Exports of Manufactures. China Econ. Rev. 47, 263-273. doi:10.1016/j.chieco.2017.08.010

Zhang, Y.-J., Peng, Y.-L., Ma, C.-Q., and Shen, B. (2017). Can Environmental Innovation Facilitate Carbon Emissions Reduction? Evidence from China. Energy Policy. 100, 18-28. doi:10.1016/j.enpol.2016.10.005

Zheng, D., and Shi, M. (2017). Multiple Environmental Policies and Pollution Haven Hypothesis: Evidence From China's Polluting Industries. J. Clean. Prod. 141, 295-304. doi:10.1016/j.jclepro.2016.09.091

Zhou, Y., Bao, M., Chen, X., and Xu, X. (2016). Co-op Advertising and Emission Reduction Cost Sharing Contracts and Coordination in Low-Carbon Supply Chain Based on Fairness Concerns. J. Clean. Prod. 133, 402-413. doi:10.1016/ j.jclepro.2016.05.097

Conflict of Interest: The authors declare that the research was conducted in the absence of any commercial or financial relationships that could be construed as a potential conflict of interest.

Publisher's Note: All claims expressed in this article are solely those of the authors and do not necessarily represent those of their affiliated organizations, or those of the publisher, the editors and the reviewers. Any product that may be evaluated in this article, or claim that may be made by its manufacturer, is not guaranteed or endorsed by the publisher.

Copyright $\odot 2021$ Deqiang, Zhijun, Hajduk-Stelmachowicz, Larik and Rafique. This is an open-access article distributed under the terms of the Creative Commons Attribution License (CC BY). The use, distribution or reproduction in other forums is permitted, provided the original author(s) and the copyright owner(s) are credited and that the original publication in this journal is cited, in accordance with accepted academic practice. No use, distribution or reproduction is permitted which does not comply with these terms. 